\title{
Analysis of the Planetary Boundary Layer Height during DISCOVER-AQ Baltimore-Washington, D.C., with Lidar and High-Resolution WRF Modeling
}

 \\ Amy Jo SCARINo, ${ }^{\mathrm{e}, \mathrm{f}}$ PhILIP DeCOla,,${ }^{\mathrm{g}, \mathrm{h}}$ Richard FERRARE, ${ }^{\mathrm{e}}$ Micheal Hicks, ${ }^{\mathrm{i}}$ \\ REBECCA D. ADAMS-SELIN, ${ }^{\mathrm{j}}$ AND ELLSWORTH J. WELTON ${ }^{\mathrm{b}}$ \\ ${ }^{a}$ Atmospheric and Environmental Research, Lexington, Massachusetts \\ ${ }^{\mathrm{b}}$ NASA Goddard Space Flight Center, Greenbelt, Maryland \\ ${ }^{\mathrm{c}}$ University of Maryland Baltimore County, Baltimore, Maryland \\ ${ }^{\mathrm{d}}$ Universities Space Research Association, Goddard Earth Sciences Technology and Research, Columbia, Maryland \\ ${ }^{\mathrm{e}}$ NASA Langley Research Center, Hampton, Virginia \\ ${ }^{\mathrm{f}}$ Science Systems and Applications, Inc., Hampton, Virginia \\ ${ }^{\mathrm{g}}$ Sigma Space Corporation, Lanham, Maryland \\ ${ }^{\mathrm{h}}$ Department of Atmospheric and Oceanic Sciences, University of Maryland, College Park, College Park, Maryland \\ ${ }^{\mathrm{i}}$ NOAA/National Weather Service, Falls Church, Virginia \\ ${ }^{\mathrm{j}}$ Atmospheric and Environmental Research, Offut Air Force Base, Nebraska
}

(Manuscript received 17 January 2018, in final form 12 June 2018)

\begin{abstract}
The daytime planetary boundary layer (PBL) was examined for the Deriving Information on Surface Conditions from Column and Vertically Resolved Observations Relevant to Air Quality (DISCOVER-AQ) Baltimore (Maryland)-Washington, D.C., campaign of July 2011 using PBL height (PBLH) retrievals from aerosol backscatter measurements from ground-based micropulse lidar (MPL), the NASA Langley Research Center airborne High Spectral Resolution Lidar-1 (HSRL-1), and the Cloud-Aerosol Lidar with Orthogonal Polarization (CALIOP) on the Cloud-Aerosol Lidar and Infrared Pathfinder Satellite Observations (CALIPSO) satellite. High-resolution Weather Research and Forecasting (WRF) Model simulations with horizontal grid spacing of $1 \mathrm{~km}$ and different combinations of PBL schemes, urban parameterization, and sea surface temperature inputs were evaluated against PBLHs derived from lidars, ozonesondes, and radiosondes. MPL and WRF PBLHs depicted a growing PBL in the morning that reached a peak height by midafternoon. WRF PBLHs calculated from gridded output profiles generally showed more rapid growth and higher peak heights than did the MPLs, and all WRF-lidar differences were dependent on model configuration, PBLH calculation method, and synoptic conditions. At inland locations, WRF simulated an earlier descent of the PBL top in the afternoon relative to the MPL retrievals and radiosonde PBLHs. At Edgewood, Maryland, the influence of the Chesapeake Bay breeze on the PBLH was captured by both the ozonesonde and WRF data but generally not by the MPL PBLH retrievals because of generally weaker gradients in the aerosol backscatter profile and limited normalized relative backscatter data near the top height of the marine layer.
\end{abstract}

\section{Introduction}

Accurate knowledge of the planetary boundary layer (PBL), through which the exchange of heat, moisture, momentum, and trace constituents between the surface and the free troposphere takes place, is central to understanding weather systems, assessing the causes of poor air quality, and estimating the sources of climate altering greenhouse gases through inverse methods. The

Corresponding author: Jennifer D. Hegarty, jhegarty@aer.com top of the PBL is typically the height above ground level (AGL) to which surface emissions are readily mixed, and it therefore affects surface pollutant concentrations. Modeling errors in the PBL height (PBLH) lead to proportional errors in top-down (inverse) estimates of emissions (e.g., Lin et al. 2003; Gerbig et al. 2008). The PBLH is also a key parameter for numerical weather prediction (e.g., Browning et al. 2007) and for estimating surface fine particulate matter concentrations from satellite-derived aerosol optical depth measurements (e.g., Cordero et al. 2013). 
The PBL typically follows a diurnal cycle, with rapid growth in the morning to a convective 1-3-km-deep mixed layer by midafternoon (Stull 1988). In the late afternoon, the top of this mixed layer can begin to descend in response to a decrease in sensible heat flux from the ground (e.g., Lothon et al. 2014). During the evening when the sensible heat flux becomes negative a stable nocturnal boundary layer (NBL) a few hundred meters deep forms, often under a relatively well-mixed layer left over from the daytime PBL, known as the residual layer (Stull 1988). Mesoscale circulations, such as sea and bay breezes, which advect cooler more stable marine air over land can disrupt this growth cycle in coastal areas (e.g., Berman et al. 1999; Stauffer et al. 2015; Loughner et al. 2014), and the differential heating associated with different surface types and land use (e.g., urban versus rural) may cause large differences in PBLH over short distances (Spangler and Dirks 1974; Hildebrand and Ackerman 1984; Trainer et al. 1995; Banta et al. 1998; Angevine et al. 2003; Bohnenstengel et al. 2015). The twice-daily launches of radiosondes from the comparatively sparse global network, typically at 0000 and 1200 UTC, do not provide adequate coverage to resolve the spatiotemporal differences associated with land surface variability, the diurnal growth cycle, and episodic mesoscale circulations. Meteorological modeling attempts to fill the general dearth of PBLH measurements and can potentially uncover the physical interactions that drive PBL variability by providing increased temporal and spatial coverage. However, models generally have difficulty simulating the PBL, particularly during the stable and transitional phases (e.g., Gerbig et al. 2008; Angevine et al. 2012; McKain et al. 2012; Nehrkorn et al. 2013). Thus, more research is necessary to improve modeling of the PBL and this requires accurate, spatially and temporally representative observations of the PBL structure to evaluate model developments.

Lidar measurements of aerosol backscatter from the ground, aircraft, and satellites offer a potentially powerful tool for determining the PBLH, reflecting the fact that the PBL typically has a much higher aerosol concentration than the free troposphere above and thus provides a stronger backscatter signal. These vertical gradients in backscatter are used in algorithms to determine the PBLH and other features such as the residual layer and entrainment zones (Melfi et al. 1985; Flamant et al. 1997; Kiemle et al. 1997; Davis et al. 1997, 2000; Brooks 2003; Grabon et al. 2010).

The higher aerosol concentrations in the PBL are due to vertical mixing of surface emissions, and thus the top of this mixing layer is also referred to as the mixed-layer height in lidar studies (e.g., Hayden et al. 1997; Scarino et al. 2014). The convective daytime PBL is often well mixed throughout its depth, and therefore the top of the mixed layer and top of the PBL can be thought of as the same. However, at other times a stable thermal layer may form under a well-mixed layer around sunset or from a sea breeze. The top of this layer will also be considered the PBL top for this study, and it may or may not be detectable by a lidar system depending on the minimum height of scattering detection by the lidar.

Ground-based systems such as the micropulse lidar (MPL) can be used to characterize the full diurnal evolution of the PBLH at a point location. Such a system has been deployed at the Goddard Space Flight Center (GSFC) since 2001 (Lewis et al. 2013). Additionally, airborne lidars such as the High Spectral Resolution Lidar (HSRL) have been used to estimate PBLHs during field measurements campaigns (e.g., Lewis et al. 2010; Baker et al. 2013; Scarino et al. 2014). Since 2006, the Cloud-Aerosol Lidar with Orthogonal Polarization (CALIOP) on board the Cloud-Aerosol Lidar and Infrared Pathfinder Satellite Observations (CALIPSO) satellite has been providing measurements of aerosol backscatter, which have been used to estimate PBLHs with global coverage (McGrath-Spangler and Denning 2012, 2013). Although airborne and satellite lidars can provide a characterization of the spatial variability, they cannot capture the diurnal evolution of PBLH at a given location provided by stationary systems like the MPL. The Deriving Information on Surface Conditions from Column and Vertically Resolved Observations Relevant to Air Quality (DISCOVER-AQ; http://discoveraq.larc.nasa.gov) Baltimore-Washington, D.C. (BW), field campaign that took place in July of 2011 included the deployment of seven land-based MPLs and one shipboard MPL, the NASA Langley Research Center (LaRC) airborne HSRL, version 1 (HSRL-1), and frequent ozonesondes during nonstandard radiosonde times. It thus provided an excellent opportunity to examine both the spatial and temporal variability of the PBLH across an urban corridor adjacent to a coastline.

In this study, we analyzed daytime PBLH retrievals from the ground-based, airborne, and satellite lidar measurements made during DISCOVER-AQ and compared them with simulations with the Weather Research and Forecasting (WRF) Model run with a 1-km inner horizontal grid and with several different combinations of PBL parameterizations, land surface model options accounting for the urban landscape of BW, and sea surface temperature (SST) inputs. These simulations were evaluated to gain a better understanding of the factors influencing the evolution of the simulated PBL. The lidar observations were used to evaluate the ability of the WRF Model to capture some of the key aspects of the PBL evolution and quantify model errors using comparable methods as some recent studies (e.g., 
Angevine et al. 2012; Scarino et al. 2014; Banks et al. $2015,2016)$. This study is unique in that multiple lidars from different platforms are used in conjunction with high-resolution WRF data for the entire month of July 2011. In addition, we look specifically into the effect of urban parameterization schemes and evaluate the model's sensitivity to them. The key questions of this study are 1) Do the multiple lidars capture the spatial variability of the PBL across the urban and coastal region and the temporal variability associated with the diurnal cycle? 2) Can the lidars capture changes in the PBLH that are due to episodic mesoscale events such as bay breezes? and 3) Do the WRF simulations accurately reproduce the spatiotemporal variability of the PBLH depicted by the lidars, and how are they affected by changes in WRF configuration?

\section{Observations}

DISCOVER-AQ was a 4-yr NASA Earth Venture field campaign for monitoring air quality that included different components focusing on different regions. One component took place during the entire month of July 2011 with a series of instrumented flights of the NASA UC-12 and NASA's P-3B over the BW area. Coinciding with the flights were the deployment of special groundbased measurement systems and the launch of ozonesondes at nonstandard radiosonde times. This extensive deployment of measurement systems provided a golden opportunity to study the structure of the PBL over the BW urban corridor.

\section{a. Micropulse lidar}

There were data from eight MPL or mini-MPL deployments available for the analysis of July 2011 with locations shown in Fig. 1. The mini-MPL instruments (Ware et al. 2016) are a newer, smaller, more portable version of the MPL with similar capabilities for determining the PBLH and thus will be referred to hereinafter as MPLs for simplicity. The MPLs at GSFC and the University of Maryland Baltimore County (UMBC) are part of the global NASA federated Micropulse Lidar Network (MPLNET) designed to measure aerosol and cloud vertical structure continuously over long time periods (Welton et al. 2001) and were operating continuously with limited data gaps throughout the DISCOVER-AQ campaign. In addition to these, an MPL unit was deployed at Edgewood, Maryland (EDGE), near the western shore of the Chesapeake Bay and also provided continuous coverage during the campaign, enabling a sampling of PBLHs from a coastal location. The four other MPLs at Beltsville, Essex, and Fairhill, Maryland, and on board the NOAA ship in the Chesapeake Bay operated for only part of the month,



FIG. 1. Locations of MPL and mini-MPL deployments during the BW DISCOVER-AQ field campaign of July 2011 plotted on the WRF 1-km domain. MPL systems were deployed at the NASA MPLNET GSFC and UMBC sites, the Sterling NWS site, and Fairhill, and mini-MPLs were deployed at the other sites.

or in the case of Fairhill had problems with data quality (T. Berkoff 2015, personal communication), and provided valuable, but more limited, information. In addition to the MPLNET and DISCOVER-AQ deployments, an MPL operated by the NOAA/National Weather Service (NWS) Office of Observations (OBS) Sterling Field Support Center in Sterling, Virginia (STER), was in service during DISCOVER-AQ. Although the MPL data from STER had gaps, it was included in this analysis because of the daily operational radiosonde launches from this location. Data from these 0000 UTC (1900 LST) radiosondes are particularly useful for validating the MPL PBLHs around the time near the evening transition from a convective PBL to a stable NBL.

The PBLHs from the MPLs were retrieved using the algorithm described by Lewis et al. (2013). In brief, the algorithm uses a combination of the wavelet covariance transform (WCT; Davis et al. 2000; Brooks 2003) with a first-derivative Gaussian wavelet and the Canny edge detection method (Canny 1986) to identify features from 5-min averages of the aerosol backscatter profile. The algorithm outputs three feature heights: the altitude of the lowest feature and the altitudes of the two largest peaks in the WCT. A fuzzy logic algorithm (Klir and Yuan 1997; Bianco and Wilczak 2002) that considers the local time of day, variance in lidar backscatter profiles, and recent PBLH retrievals is used to select an appropriate PBLH from the three feature heights. Since clouds may interfere with the PBLH retrieval, for the monthlong statistical analysis presented in section 4 all 
cloudy lidar profiles $(\sim 35 \%$ of the total $)$ were automatically screened out as in Lewis et al. (2013). For the individual-day case studies presented in section 5, only cloudy profiles that were determined to interfere with the PBLH retrievals were removed manually.

Currently the standard MPL has a minimum range for scattering detection of $250 \mathrm{~m}$ and the mini-MPL has a minimum range for scattering detection of $100 \mathrm{~m}$. However, at the time of DISCOVER-AQ in 2011, the MPL normalized relative backscatter (NRB) vertical profile data were not considered to be reliable at ranges shorter than $340 \mathrm{~m}$. The PBLH retrieval algorithm (e.g., Lewis et al. 2013) works by analyzing features in the NRB profiles acquired by the lidar. Because the DISCOVER-AQ MPL NRB profiles only begin at $340 \mathrm{~m}$ AGL, the lowest possible PBLH retrieval was limited to about $450 \mathrm{~m}$ AGL. This effectively limited the analysis of these lidar data to the daytime hours, since the NBL often has a top at lower heights (Stull 1988). This limitation also precluded extensive use of the shipboard PBLH measurements as typically the simulated PBLH was near or below this height limit. Newer MPLs have better sensitivity near the ground and have demonstrated the ability to detect NRB profiles down to about $150 \mathrm{~m} \mathrm{AGL}$ and therefore shallow PBL tops of $\sim 250 \mathrm{~m}$ AGL or lower (e.g., Ware et al. 2016).

\section{b. Airborne high-spectral-resolution lidar}

Measurements from the NASA LaRC airborne HSRL-1 were available on 13 flight days during DISCOVER-AQ. On each flight day, the NASA LaRC UC-12 aircraft made several daytime transects across the $\mathrm{BW}$ region, concentrating on the urban corridor. Determination of the PBLH from HSRL-1 measurements in this study closely follows the procedure described by Scarino et al. (2014). In brief, the PBLHs are calculated from aerosol backscatter profiles that are input into a Haar wavelet algorithm (Brooks 2003). The profiles are computed every $0.5 \mathrm{~s}$ using a 10 -s running average of the 532-nm backscatter data (Hair et al. 2008). The aerosol backscatter values are averaged over 1000-m horizontal and 30-m vertical resolution (Rogers et al. 2009). Cloudy lidar profiles identified by the presence of much stronger backscatter gradients compared to weaker aerosol gradients following Davis et al. (2000) and Burton et al. (2010) were discarded since these gradients can be misinterpreted by the wavelet algorithm as the PBL top.

\section{c. CALIPSO-CALIOP}

Launched in 2006 as part of the A-Train of satellites, the CALIOP instrument aboard the CALIPSO satellite is optimized for aerosol and cloud measurements, making it sensitive to the top of the PBL (Winker et al. 2007;
McGrath-Spangler and Denning 2012, 2013). The A-Train constellation has a 705-km sun-synchronous orbit, an equator crossing time of about 1330 LST, and a 16-day repeat cycle (Winker et al. 2007, 2009), providing PBLH observations in the afternoon roughly every two weeks. Most observations occur between 1300 and 1400 LST except at high latitudes where longer summertime day lengths extend daytime observations (McGrath-Spangler and Denning 2013). During DISCOVER-AQ, there were three orbits with ground tracks that passed within the WRF inner 1-km domain on 14, 23, and 30 July. The PBLH can be retrieved using the CALIPSO-CALIOP 532-nm total attenuated backscatter data following the algorithm of Jordan et al. (2010) and McGrath-Spangler and Denning $(2012,2013)$. Hereinafter, all of the CALIPSOCALIOP data will be referred to as just CALIPSO.

\section{WRF Model}

\section{a. WRF configurations and initial evaluation}

The meteorological conditions during the DISCOVERAQ period of July 2011 were simulated with the Advanced Research WRF (Skamarock and Klemp 2008; Wang et al. 2015), version 3.6.1, hereinafter referred to simply as WRF. WRF was configured with four two-way horizontal nests with grid sizes of $27,9,3$, and $1 \mathrm{~km}$. The innermost domain was centered on the BW region (Fig. 1). The vertical coordinate was terrain following with 59 levels, including 34 in the first $2 \mathrm{~km}$ above the ground to better resolve gradients within the PBL. The initial and boundary conditions were supplied by the North American Regional Reanalysis (NARR; Mesinger et al. 2006) that has an approximate horizontal grid size of $32 \mathrm{~km}$ and is available every $3 \mathrm{~h}$. The modeling periods were composed of independent $30-\mathrm{h}$ simulations initialized at 0000 UTC (1900 LST) each day, with the first $6 \mathrm{~h}$ of each simulation discarded as model spinup. Grid nudging to the NARR fields at 3-h intervals in the outer domain above the model PBL was used to minimize model drift.

The WRF runs used either the Mellor-Yamada-Janjić (MYJ; Janjić 1994, 2001) or the Bougeault-Lacarrère (BouLac; Bougeault and Lacarrere 1989) PBL schemes. Both are local mixing schemes that use turbulence kinetic energy (TKE) thresholds to determine the PBL top. These two were selected from among the 13 total PBL schemes available in WRF, because they could be coupled with the multilayer Building Environment Parameterization + Building Energy Model (BEPBEM) urban canopy model (UCM; Martilli et al. 2002; Salamanca and Martilli 2010). A single-layer UCM (Kusaka et al. 2001) is available in WRF and can be used with many different PBL schemes. However, it requires 
TABLE 1. WRF configurations showing the PBL scheme used, whether the BEPBEM UCM is activated (yes) and whether the MURSST is used (yes). The default SST is provided from NARR if MURSST is not used (no). The configurations selected for detailed study are shown in boldface type.

\begin{tabular}{llcc}
\hline \multicolumn{1}{c}{ Configuration name } & PBL scheme & BEPBEM UCM & MURSST \\
\hline MYJ-BEPBEM-MURSST & MYJ & Yes & Yes \\
BouLac-BEPBEM-MURSST & BouLac & Yes & No \\
MYJ-noUCM-noMURSST & MYJ & No & No \\
BouLac-noUCM-noMURSST & BouLac & Yes & No \\
MYJ-BEPBEM-noMURSST & MYJ & Yes & No \\
BouLac-BEPBEM-noMURSST & BouLac & No & Yes \\
MYJ-noUCM-MURSST & MYJ & No & Yes \\
BouLac-noUCM-MURSST & BouLac & & \\
\hline
\end{tabular}

that the average building heights within each grid box be lower than the depth of the lowest model layer. Given the shallow depth of the lowest model layer for our vertical grid this condition would have been violated for some urban grid points, and therefore it was only possible to use the multilayer BEPBEM UCM.

The UCM is an option available in WRF with the Noah land surface model (Chen and Dudhia 2001; Mitchell et al. 2005) and simulates the bulk effect of buildings (e.g., wind flow and heating) in the urban "canopy." Previous studies indicated that the UCM was helpful for simulating the meteorological conditions of urban regions at high resolution (e.g., Chen et al. 2011a, b; Nehrkorn et al. 2013; Monaghan et al. 2014). It recognizes three urban land classes derived from the 30-mresolution 2006 National Land Cover Database and uses city-specific parameters on building heights, distribution, and area coverage, from the National Urban Data and Access Portal Tool (NUDAPT-44) database (Chen et al. 2011b).

The WRF sensitivity to SST in the Chesapeake Bay was evaluated by inputting either the Multisensor Ultrahigh Resolution daily SST analysis on a global $\sim 1$-km grid (MURSST; Chin et al. 2013) or the $\sim 32-\mathrm{km}$ SST fields from NARR. In general, the MURSST SSTs in Chesapeake Bay were 2-5K warmer than the NARR SSTs and in closer agreement with National Buoy Data Center observations. The diurnal SST cycle was parameterized by adding a perturbation based on buoy observations and bathymetry to the MURSST. However, the maximum perturbation amplitude from the buoys was found to be only $\sim 0.4 \mathrm{~K}$ and therefore much smaller than the MURSST-NARR difference.

Overall, eight different WRF Model configurations were tested (Table 1). For each PBL scheme the BEPBEM UCM was either on or off, the MURSST was either used or not, or both the UCM and MURSST were used or not. All eight sets of WRF runs were objectively evaluated using the WRF-Model Evaluation Tools, version 5.0 (WRF-MET; http://www.dtcenter.org/met/users/), software, which generates a comprehensive set of model performance statistics by comparing model fields against a variety of observational datasets. The performance statistics for the surface variables in the 1-km domain were examined in detail to discover any systematic biases related to each WRF configuration; however, only a brief summary is presented here.

The average biases for the 2-m temperature and 10-m wind speed at each hour of the day between 0500 and 2100 LST were smaller in magnitude than $2.0 \mathrm{~K}$ and $2 \mathrm{~m} \mathrm{~s}^{-1}$, respectively, for all model configurations. The BouLac runs had higher afternoon temperature biases than the MYJ runs. The noUCM runs had higher temperature biases than the BEPBEM runs regardless of whether combined with the BouLac or MYJ PBL. In addition, the noUCM runs had afternoon wind speed biases of $0.5-2.0 \mathrm{~m} \mathrm{~s}^{-1}$, while the BEPBEM runs had very small biases. Spatially, areas with larger bias and root-mean-square (RMS) error tended to be concentrated near and just downwind (typically north and east) of the cities of Washington, D.C., and Baltimore in the runs that did not utilize the BEPBEM. The differences attributed to the MURSST were much smaller. In general, the noMURSST runs had slightly lower biases $(\sim 0.2 \mathrm{~K})$ than the MURSST runs, likely because of the influence of the colder NARR Chesapeake Bay SSTs. However, there was no significant impact on nearsurface wind speeds.

On the basis of this initial evaluation, which indicated that the WRF performance was similarly sensitive to the BEPBEM and MURSST regardless of PBL scheme used, only four of the eight WRF configurations are considered in the remainder of the paper to simplify the presentation. These are the MYJ-BEPBEM-MURSST, BouLacBEPBEM-MURSST, MYJ-noUCM-MURSST, and MYJ-BEPBEM-noMURSST configurations.

\section{b. PBLH calculation}

Each WRF PBL scheme has a different method for diagnosing the PBLH and this complicates comparisons 




FIG. 2. Time-height cross sections of WRF-simulated vertical potential temperature gradients ( $d \theta / d z$; color filled; $\mathrm{K} \mathrm{km}^{-1}$ ) for $14 \mathrm{Jul} 2011$ at UMBC with the MYJ-BEPBEM-MURSST configuration. The MPL PBLH retrievals are plotted as gray dots. The MYJ PBL scheme TKE diagnostic PBLHs are plotted as plus signs, BRN are plotted as asterisks, PAR are plotted as triangles, and GRD are plotted as open circles.

of the PBLH from WRF using different PBL schemes. Furthermore, local mixing schemes like MYJ are very sensitive to high-frequency TKE fluctuations associated with turbulent eddies that develop in the afternoon convective boundary layer. Since these eddies are only partially resolvable at horizontal grid sizes of a few kilometers this grid scale is referred to as the terra incognita (Wyngaard 2004) and these large TKE fluctuations in the model may be spurious (LeMone et al. 2013). The potential effect on the PBLH diagnostic is illustrated by the time-height cross section of WRF MYJ-BEPBEMMURRSST vertical potential temperature gradients $(d \theta / d z)$ at UMBC plotted with the MPL PBLH retrieval and the WRF MYJ PBLH diagnostic shown in Fig. 2. WRF produces a plausible vertical thermal structure for which the highest gradients correspond to MPL PBLHs. However, after 1100 LST the MYJ PBLH displays large unrealistic high-frequency fluctuations from $>2.0 \mathrm{~km}$ to $<0.5 \mathrm{~km}$ and back within $1 \mathrm{~h}$ of run time. Fortunately, the PBLH could also be calculated directly from the gridded WRF outputs with methods that are not as sensitive to the TKE fluctuations (also shown in Fig. 2). For this study, we used the bulk Richardson number (BRN; Seidel et al. 2012), the parcel method (PAR; Holzworth 1964; Seibert et al. 2000) and the gradient method (GRD; Heffter 1980; Seidel et al. 2010). The BRN is calculated using buoyancy and wind shear terms and the PBLH corresponds to the height interpolated between two data levels at which a critical value of 0.25 is exceeded. The PAR method defines the PBLH as the height interpolated between two data levels at which the potential temperature exceeds the surface potential temperature. The GRD method sets the PBLH at the base of the first inversion layer above the ground containing a gradient exceeding $3 \mathrm{~K} \mathrm{~km}^{-1}$. Hereinafter, we will only refer to WRF PBLHs calculated with these three methods and not the diagnostics from the PBL schemes. These methods were also used to calculate the PBLH from ozonesondes and the STER radiosonde data.

\section{Analysis of PBLH for July 2011}

\section{a. Evaluation of MPL PBLH with ozonesondes}

The DISCOVER-AQ field campaign provided an opportunity to evaluate PBLH retrievals during the daytime growth period because, as part of the field campaign, ozonesondes, which included temperature, humidity, and winds, were launched from two locations, the Howard University Beltsville Center for Climate System Observation in Beltsville (BELT) and EDGE, between 0600 and 1700 LST. Following Lewis et al. (2013), retrievals of PBLH from the MPLs at the BELT and EDGE sites were averaged to 20-min temporal resolution centered on the time of the ozonesonde launch and were compared with PBLHs derived from 17 

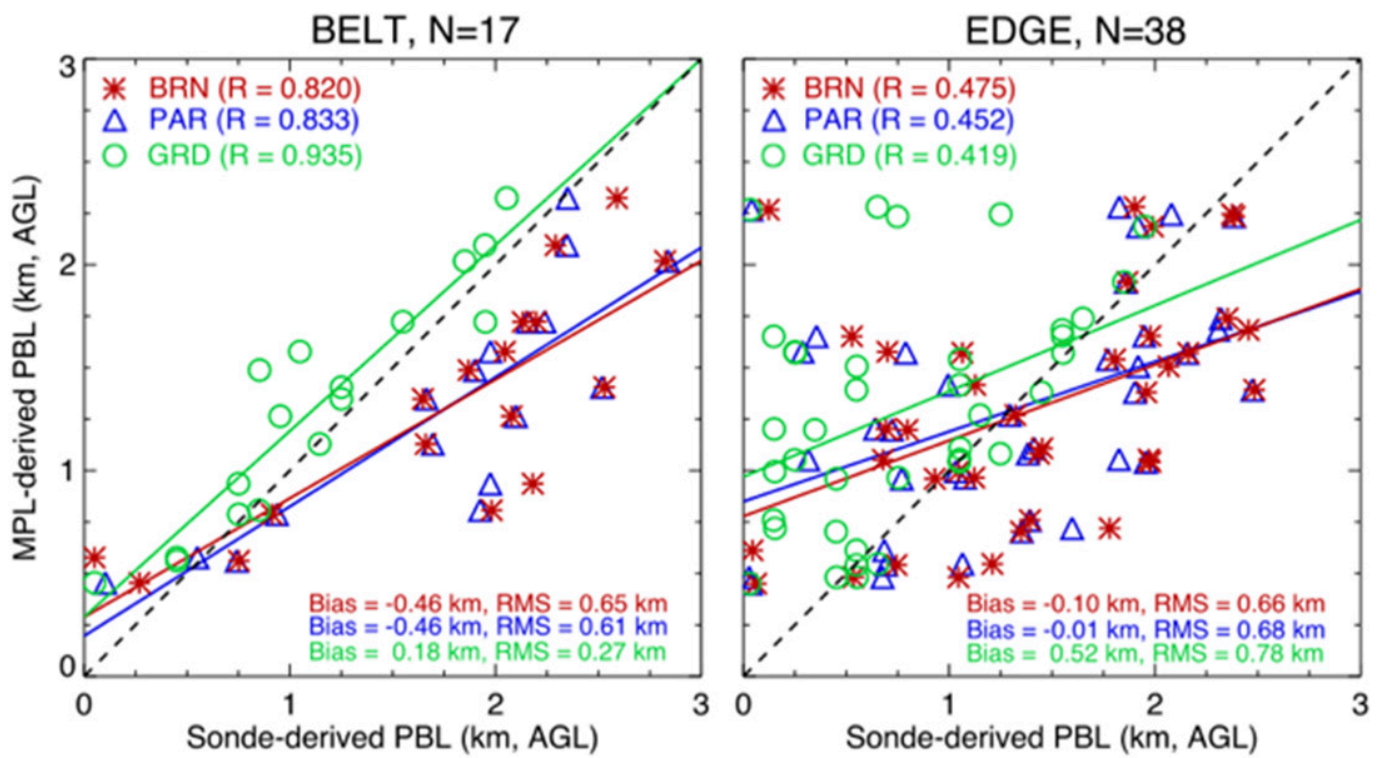

FIG. 3. MPL vs ozonesonde PBLH scatterplot for (left) BELT and (right) EDGE. The ozonesonde PBLHs were calculated using the BRN (red), PAR (blue), and GRD (green) methods. Correlation statistics for each method are shown in the upper left of each panel, and bias (MPL - ozonesonde) and RMS difference are shown in the lower right.

and 38 ozonesondes from BELT and EDGE, respectively. At BELT, the lidar-derived PBLHs correlated well with the ozonesonde PBLHs, with correlation coefficient $R=0.82,0.83$, and 0.93 for the BRN, PAR, and GRD methods, respectively, and had MPL-ozonesonde biases of $-0.46 \mathrm{~km}$ for the BRN and PAR methods and $0.18 \mathrm{~km}$ for the GRD method (Fig. 3). The correlation at EDGE was not as good, with $R=0.48,0.45$, and 0.42 , and, although the biases were better or comparable to those at BELT $(-0.10,-0.01$, and $0.52 \mathrm{~km}$, respectively), the root-mean-square difference (RMSD) values in all cases were larger. Note that BRN and PAR methods produce PBLHs that are interpolated between observational levels whereas the GRD is defined at the base of an inversion layer. Since the BRN and PAR criteria for PBLH are often achieved within this layer the PBLHs from these methods tend to be higher than the GRD PBLH contributing to the different signs of the biases. The poorer agreement at EDGE is possibly due to its proximity to the Chesapeake Bay as frequent incursions of marine air over land by the Chesapeake Bay breeze introduce stable layers that effectively reduced the mixing height to levels that were below or near the lower height limit of the available MPL NRB data and therefore difficult to detect. Furthermore, the aerosol gradients at the height of the PBL top during these bay-breeze events are generally much weaker than at the height of the overlying residual layer, which contributes to the difficulty in retrieving the proper PBLH from the MPL. Similarly, Stauffer et al. (2015) reported poor MPL-ozonesonde agreement because of shallower and weaker temperature inversions common at EDGE.

\section{b. MPL and WRF PBLH diurnal cycle}

The average daytime PBLHs for July 2011 at GSFC, UMBC, and EDGE from the MPLs and WRF MYJBEPBEM-MURSST and BouLac-BEPBEM-MURRST configurations are shown in Fig. 4. In general, the average WRF PBLHs started growing rapidly after 0700 LST from just above the surface while the average MPL PBLHs showed notable growth only after 0800 LST from about $0.5 \mathrm{~km}$. Also, WRF PBLHs grew more rapidly, reaching an average peak at GSFC and UMBC locations of $\sim 2 \mathrm{~km}$ as compared with the MPLs average peaks of $\sim 1.7 \mathrm{~km}$. At these times and locations, the GRD method seems to be a better match to the retrievals than the BRN and PAR. However, both the GRD and PAR methods produced lower PBLHs around sunset than indicated by the MPL or the BRN method. In general, WRF PBLHs decreased more rapidly in the afternoon than the MPL values. At EDGE, the average WRF PBLH reached a lower peak than the inland sites and decreased much earlier in the afternoon, possibly because of the simulated influence of cooler marine air transported onshore by the bay breeze. However, the MPL retrievals did not seem to reflect the influence of the bay breeze. The other WRF configurations produced similar diurnal patterns of PBL growth and descent (not shown) with the main differences being in the average PBLH peak. 

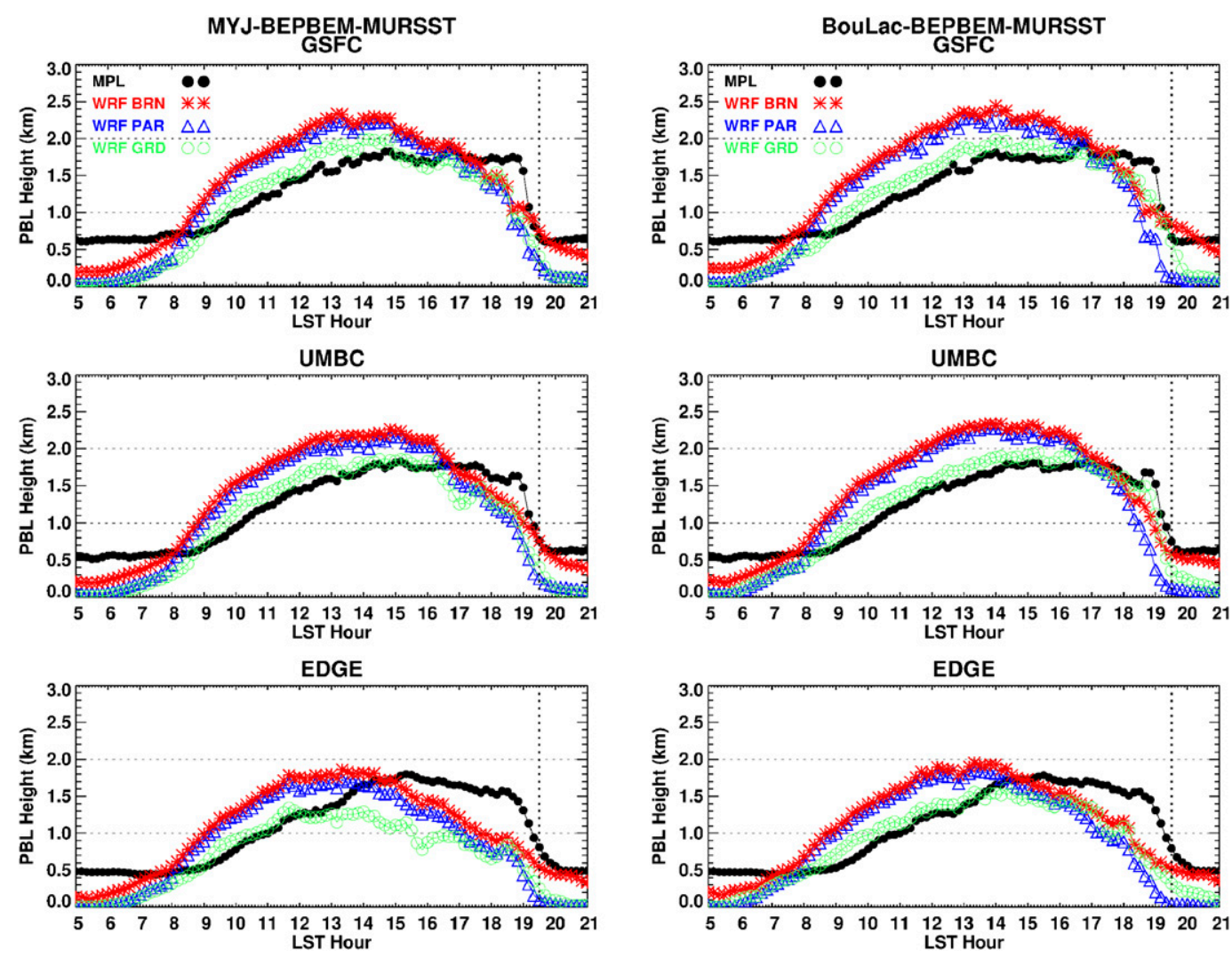

FIG. 4. Average PBLH daytime cycle at (top) GSFC, (middle) UMBC, and (bottom) EDGE for July 2011 from MPL retrievals (same on both sides) and (left) MYJ-BEPBEM-MURSST and (right) BouLac-BEPBEMMURSST WRF runs. All heights are shown as AGL. The WRF PBLHs are calculated from WRF gridded outputs using the BRN, PAR, and GRD. The average July sunset time for BW at $\sim 1930$ LST is shown as a vertical dotted line; the average July sunrise time is a few minutes before 0500 LST.

Performance statistics for the WRF PBLH simulations are shown in Table 2 for the UMBC and EDGE sites for each of the four WRF configurations selected for detailed analysis. The GSFC statistics were similar to those of UMBC and are not shown. At UMBC the biases ranged from 0.14 to $0.45 \mathrm{~km}$ for the $\mathrm{BRN}$ and
PAR methods but were near zero for the GRD method. The GRD biases compare favorably to those reported by Feng et al. (2016) using the same method to compare PBLHs derived from a similarly configured WRF with ceilometer PBLH estimates over southern California during California Research at the Nexus of Air Quality

TABLE 2. The WRF correlation, bias ( $\mathrm{km}$; WRF - MPL), and root-mean-square difference $(\mathrm{km})$ for PBLH when compared with MPL PBLHs at UMBC and EDGE for 0700-2000 LST. The WRF PBLHs are calculated using the BRN, PAR, and GRD methods, and the statistics are listed in that order in each cell.

\begin{tabular}{lccr}
\hline \hline \multicolumn{1}{c}{ WRF configuration } & $R$ & Bias & RMSD \\
\hline UMBC & & & $0.35,0.22,0.04$ \\
BouLac-BEPBEM-MURSST & $0.57,0.57,0.62$ & $0.26,0.13,-0.07$ & $0.71,0.70,0.56$ \\
MYJ-BEPBEM-MURSSST & $0.56,0.56,0.54$ & $0.26,0.13,-0.06$ & $0.67,0.66,0.64$ \\
MYJ-BEPBEM-noMURSST & $0.56,0.57,0.54$ & $0.43,0.34,-0.08$ & $0.67,0.66,0.65$ \\
MYJ-noUCM-MURSST & $0.62,0.62,0.57$ & & $0.76,0.73,0.61$ \\
EDGE & & $0.16,0.02,-0.12$ & $0.69,0.73,0.70$ \\
BouLac-BEPBEM-MURSST & $0.42,0.39,0.43$ & $-0.08,-0.06,-0.31$ & $0.65,0.68,0.77$ \\
MYJ-BEPBEM-MURSSST & $0.45,0.42,0.38$ & $-0.02,-0.16,-0.42$ & $0.69,0.74,0.83$ \\
MYJ-BEPBEM-noMURSST & $0.38,0.35,0.34$ & $0.35,0.25,-0.31$ & $0.72,0.72,0.73$ \\
MYJ-noUCM-MURSST & $0.55,0.52,0.43$ & & \\
\hline
\end{tabular}




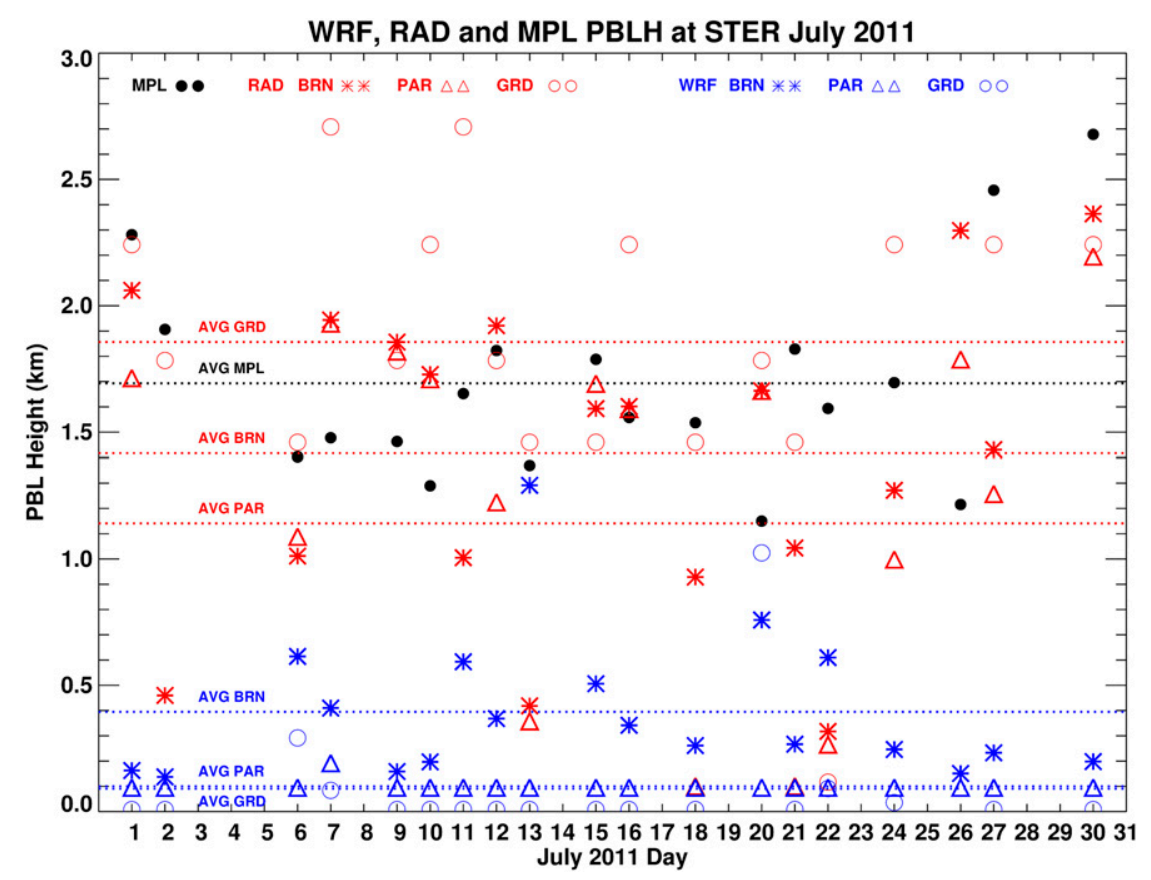

FIG. 5. The MPL, WRF, and radiosonde PBLH at STER at 1900 LST for each day in July 2011. The monthly mean PBLHs are shown for each method and data source as labeled horizontal dotted lines. All heights are shown as kilometers AGL.

and Climate Change (CalNex). They are better than those reported by Ware et al. (2016) for a WRF-miniMPL comparison at the same location during a short period in October-November 2015, when the biases ranged from 0.38 to $0.73 \mathrm{~km}$. These statistics are also qualitatively consistent with those from the MPL evaluation with ozonesondes at the nearby BELT location (Fig. 3). The biases and RMSD for the BouLac-BEPBEMMURSST and MYJ-noUCM-MURSST runs were higher at UMBC than for the other two configurations. This result is consistent with the higher afternoon biases in the 2-m temperature and 10-m wind speed associated with the BouLac and noUCM configurations discussed in section 3. At EDGE the WRF biases were much lower and in many cases negative, which is inconsistent with the MPL evaluation with ozonesondes, which in general showed the opposite sign. However, the ozonesondes were mostly launched in the late morning or early afternoon and therefore were generally too early to capture the impact of the Chesapeake Bay breeze. Replacing the MURSST with the colder NARR SSTs in the Chesapeake Bay resulted in greater negative biases in PBLH at EDGE, particularly for the GRD method $(-0.42 \mathrm{~km})$. At UMBC, farther inland, the colder SSTs had no notable effect on the statistics but produced $\sim 0.1 \mathrm{~km}$ lower average PBLHs from 1800-1900 LST (Fig. 4). The correlations at UMBC were only modest $(R=0.53-0.61)$ and much lower than those of the
MPL-ozonesonde comparison at BELT. However, they are comparable to those resulting from a comparison of Raman lidar with WRF PBLHs for locations in Europe that produced correlations of $\sim 0.2-0.6$ (Banks et al. 2015, 2016). At EDGE the correlations were lower $(R=$ $0.34-0.55$ ) but more consistent with the MPL-ozonesonde comparisons. A possible reason investigated for the low $R$ values in the current study was the inclusion of the data between 0700 and 0800 LST when the average MPL PBLHs were near the height of the lowest gradient detection and the WRF PBLHs were lower. However, removing this data resulted in slightly lower $R$ values. Further investigation revealed some cases for which the MPL PBLHs exhibited discernable growth parallel to that of WRF from 0700 to 0800 LST, which may explain why retaining these data points improved the correlation statistics.

The WRF PBLHs were also compared with MPL retrievals at STER approximately $50 \mathrm{~km}$ west of BW, because daily radiosondes launched from this location at 1900 LST provided an opportunity to evaluate both MPL retrievals and WRF PBLHs near sunset $(\sim 1930$ LST) with independent data. On all of the days with available MPL data, the MPL PBLHs were above $1.1 \mathrm{~km}$ and the average was near $1.7 \mathrm{~km}$ (Fig. 5). The radiosonde PBLHs were generally above $1.0 \mathrm{~km}$, with a few low outliers. The average radiosonde PBLHs ranged from 1.2 to $1.9 \mathrm{~km}$ depending on the PBLH calculation 
TABLE 3. The WRF PBLH correlation, bias (km; WRF - HSRL-1 or WRF - CALIPSO), and root-mean-square difference (km) when compared with HSRL-1 and CALIPSO PBLHs. The WRF PBLHs are calculated using the BRN, PAR, and GRD methods, and the statistics are listed in that order in each cell.

\begin{tabular}{lccr}
\hline \hline \multicolumn{1}{c}{ WRF configuration } & $R$ & Bias & RMSD \\
\hline HSRL-1 & & & \\
BouLac-BEPBEM-MURSST & $0.47,0.46,0.51$ & $0.22,0.16,-0.18$ & $0.78,0.77,0.67$ \\
MYJ-BEPBEM-MURSSST & $0.40,0.38,0.41$ & $0.16,0.09,-0.28$ & $0.79,0.79,0.77$ \\
MYJ-BEPBEM-noMURSST & $0.38,0.37,0.40$ & $0.07,0.01,-0.31$ & $0.82,0.83,0.79$ \\
MYJ-noUCM-MURSST & $0.46,0.44,0.47$ & $0.22,0.14,-0.30$ & $0.77,0.78,0.73$ \\
CALIPSO & & & $0.80,0.74,0.55$ \\
BouLac-BEPBEM-MURSST & $0.75,0.75,0.61$ & $0.68,0.61,0.10$ & $0.86,0.80,0.65$ \\
MYJ-BEPBEM-MURSSST & $0.74,0.75,0.66$ & $0.72,0.65,0.20$ & $0.82,0.75,0.64$ \\
MYJ-BEPBEM-noMURSST & $0.74,0.74,0.63$ & $0.69,0.61,0.17$ & $0.56,0.54,0.36$ \\
MYJ-noUCM-MURSST & $0.75,0.75,0.66$ & $0.43,0.40,0.04$ & \\
\hline
\end{tabular}

method. In contrast, the WRF PBLHs were generally below $0.5 \mathrm{~km}$. This comparison with both radiosonde and MPL data suggests that at similar inland locations WRF may be decreasing the PBLH too quickly in the afternoon.

\section{c. HSRL-1, CALIPSO, and WRF}

The WRF simulations were also evaluated with PBLH retrievals from HSRL-1 and CALIPSO data (Table 3). The WRF-HSRL-1 correlations ranged from a low of $R=0.37$ for the MYJ-BEPBEMnoMURSST PAR PBLH to a high of $R=0.51$ for the BouLac-BEPBEM-MURSST GRD PBLH. These values are somewhat lower than the WRF-Chem-HSRL mixed-layer height correlations $(R=0.4-0.68)$ for the CalNex and Carbonaceous Aerosol and Radiative Effects Study (CARES) campaigns in California reported by Scarino et al. (2014). The WRF-Chem in that study used the MYJ PBL and the PBLH was determined using a method similar to GRD (Fast et al. 2011). We hypothesize that the greater synoptic variability of the $\mathrm{BW}$ region, as compared to California, may play a role in these correlation differences. Similar to the WRF-MPL comparisons, the highest positive biases were with the BRN method and for the BouLac-BEPBEM-MURSST and MYJ-noUCM-MURSST runs, whereas the largest negative bias of $-0.34 \mathrm{~km}$ was with the GRD method for the MYJ-BEPBEM-noMURSST runs. The GRD biases are of the same sign and a similar magnitude to those reported by Scarino et al. (2014) for the coastal San Francisco CARES subset of data.

During the DISCOVER-AQ field campaign, there were only three CALIPSO orbital ground tracks that passed within the WRF 1-km domain (Fig. 6). While none of the orbital tracks significantly intersected the BW urban corridor, the retrievals along the tracks revealed some notable spatial variability in the PBLH. The track on 23 July over eastern Maryland had very high PBLHs of 2-2.5 km, whereas the tracks on 14 and 30 July through eastern Virginia and western Maryland featured much lower PBLHs of approximately $1.0-1.5 \mathrm{~km}$. The corresponding WRF values (not shown) exhibited similar spatial variability except over the bay where PBLHs were lower $(<1.5 \mathrm{~km})$. Eastern Maryland, on the "Delmarva" Peninsula, features primarily agricultural land, whereas northeastern Virginia and western Maryland consist primarily of forested, suburban, and agricultural land, and the different land use likely contributed to different PBLH spatial patterns. The only day that had both HSRL-1 and CALIPSO PBLH retrievals was 14 July. The HSRL-1 afternoon retrievals over the $\mathrm{BW}$ urban corridor were $\sim 2.0 \mathrm{~km}$ (Fig. 7) and when compared with the CALIPSO PBLH retrievals of $\sim 1.5 \mathrm{~km}$ indicated an urban-to-rural gradient of $\sim 0.5 \mathrm{~km}$.

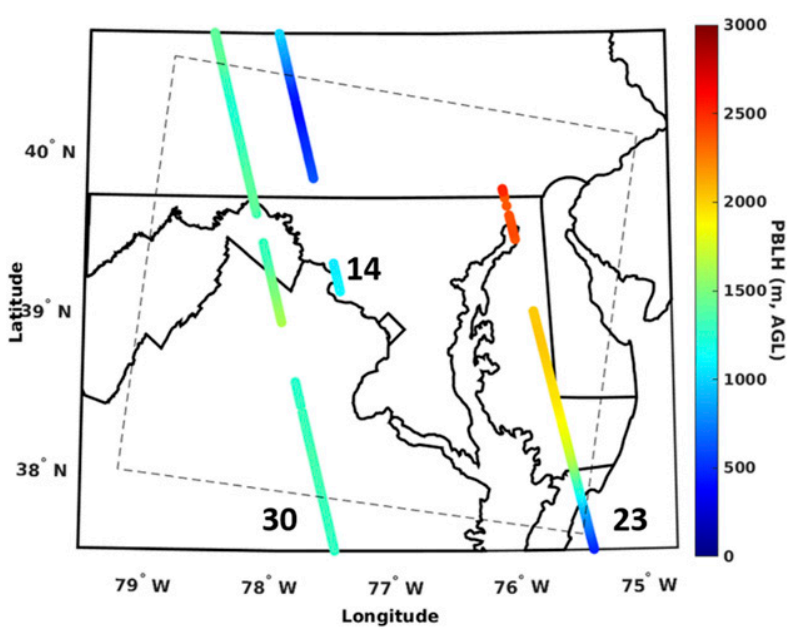

FIG. 6. CALIPSO PBLH (m AGL) along the ground orbital track for 14,23, and $30 \mathrm{Jul} 2011$. The day of the month is shown near the bottom of each track. The track on $30 \mathrm{Jul}$ has been offset by $0.5^{\circ}$ to the west to distinguish it from 14 July. The boundaries of the WRF 1-km domain are shown with dashed lines. 



FIG. 7. The WRF MYJ-BEPBEM-MURSST PBLH (m AGL) in the $1-\mathrm{km}$ domain calculated with the BRN method averaged over (top) 1450-1500 LST $11 \mathrm{Jul}$ and (bottom) 1420-1430 LST 14 Jul. The HSRL-1 PBLHs along the corresponding 10-min portion of the flight track are shown as overlapping colored circles.

The PBLH correlation statistics from 1875 WRFCALIPSO pairs ranged from $R=0.70$ to 0.75 for the $\mathrm{BRN}$ and PAR methods and from $R=0.61$ to 0.66 , for the GRD method. These correlation values are higher than those for the WRF-HSRL-1 and WRF-MPL comparisons; however, the BRN and PAR WRF biases are much higher $(>0.6 \mathrm{~km})$ while the GRD biases are better, at $\sim 0.2 \mathrm{~km}$. CALIPSO is only sampling the afternoon well-developed PBL, whereas the MPL and HSRL-1 also include periods during the PBL transition and presumably, this difference likely had some effect on the statistics. The MYJ-BEPBEM-noMURSST run had slightly lower biases, and interestingly, the MYJnoUCM-MURSST had the lowest bias values of all the WRF configurations with BRN and PAR biases of $\sim 0.4 \mathrm{~km}$ and a GRD bias of 0.04 . Given that the orbits were a significant distance from the urban corridor, one may expect the UCM to have a lesser effect than at locations closer to the cities. That it produced notably higher biases in the less urban locations was unexpected and could be explored in future studies.

\section{Daily variability of PBLH}

Important weather and air quality events such as highozone episodes in the northeastern United States develop under very specific synoptic conditions that are not necessarily reflected in the monthly averages. Therefore, to gain a better understanding of the PBLH variability in both the lidar observations and WRF, it is useful to examine individual case days. For these cases we present only WRF data for the MYJ-BEPBEM-MURSST configuration, but the general findings were similar for all configurations.

Two days with contrasting weather conditions in BW were 11 and 14 July. Observations at BaltimoreWashington International Airport (BWI) indicated that 11 July was warm, reaching a maximum temperature (Tmax) of $32^{\circ} \mathrm{C}$, and humid, with a dewpoint (Td) $>20^{\circ} \mathrm{C}$, with light $\left(<5 \mathrm{~m} \mathrm{~s}^{-1}\right)$ southwesterly winds. In contrast, 14 July was postfrontal with an anticyclone centered to the northwest of BW producing cooler and drier (Tmax = $27^{\circ} \mathrm{C} ; \mathrm{Td} \approx 14^{\circ} \mathrm{C}$ ) surface conditions and moderately brisk northeasterly wind flow $\left(\sim 10 \mathrm{~m} \mathrm{~s}^{-1}\right.$ in the morning). WRF afternoon PBLHs were also very different, being near $2.5 \mathrm{~km}$ over the BW urban corridor on 11 July, but only around $1.5 \mathrm{~km}$ on $14 \mathrm{July}$ (Fig. 7). On 11 July, the HSRL-1 PBLHs were much lower than those of WRF (Fig. 7) and there was generally poor WRF-HSRL-1 PBLH correlation ( $R=0.15,0.10$, and 0.18 for BRN, PAR, and GRD) for all the matched points along the flight tracks, while at BELT there was poor agreement between the MPL PBLHs and PBLHs derived from WRF and ozonesonde profiles (Fig. 8). For 14 July, the WRF-HSRL-1 PBLH correlation was much better $(\mathrm{R}=0.91,0.91,0.80$ for BRN, PAR, GRD) and there was good agreement between all the MPL, ozonesonde, and WRF PBLHs (Fig. 9). Other studies have found similar daily variability in the agreement between PBLHs derived from lidar backscatter data and model or radiosonde profiles that was attributable to the aerosol mixed-layer height not always corresponding to the thermodynamic mixedlayer height (Lothon et al. 2014; Ware et al. 2016). However, another interesting feature for this analysis was that on 11 July, the GRD PBLHs were up to $1.0 \mathrm{~km}$ lower than the corresponding BRN and PAR values calculated with the same WRF and ozonesonde profiles. The fact that there were such large differences between the PBLHs attributable to the calculation method, even using the same meteorological profile, further suggests that the meteorological PBL structure is less distinct and the PBLH derived from it is more uncertain on some days. For such days, the sensitivity of the PBLH calculation from meteorological variables to the method used suggests a potentially quantifiable degree of uncertainty 


\section{Beltsville 20110711}

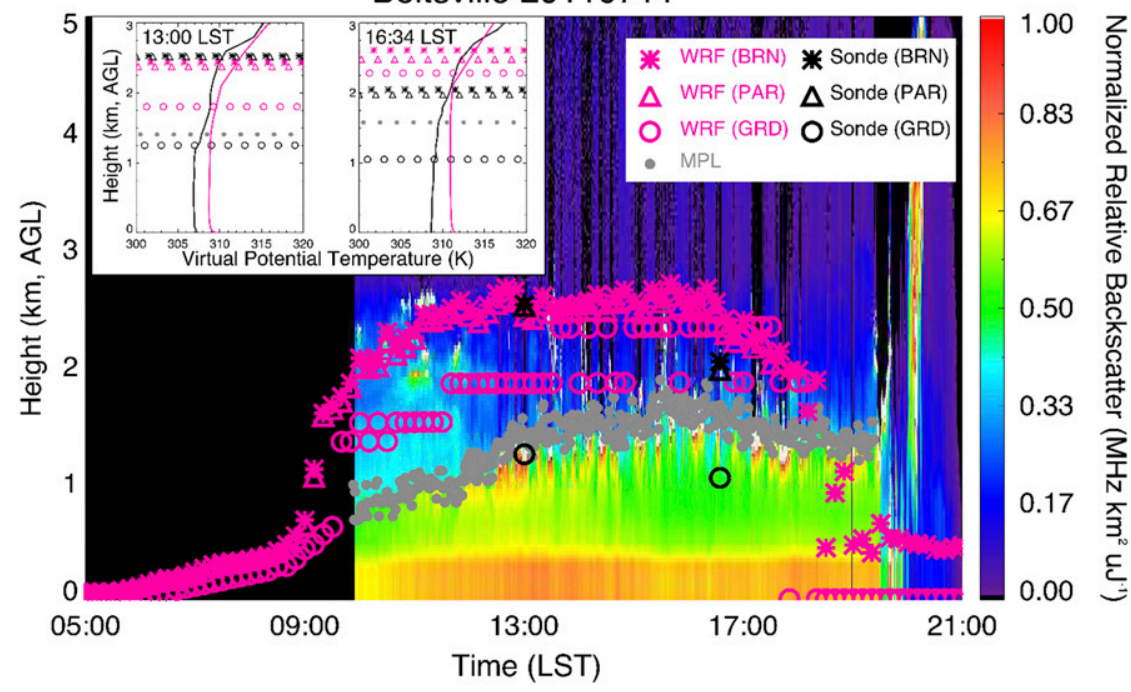

FIG. 8. The MPL aerosol backscatter curtain plot at BELT for 11 Jul 2011 with the MPL PBLH retrievals overlaid as gray dots and WRF PBLHs overlaid as pink symbols. Also shown are profiles of ozonesonde (black) and WRF (pink) virtual potential temperatures at 1300 and 1634 LST. The WRF profiles are from the closest 10-min output time. Plotted with the profiles are the corresponding MPL PBLH retrievals and ozonesonde and WRF PBLHs using the BRN (asterisks), PAR (triangles), and GRD (open circles) methods. The ozonesonde PBLHs are also overlaid on the MPL curtain plot in black. For this day, there are no MPL data at BELT before 1000 LST, and these times are shown as the background color.

in the mixing-height estimates (Seidel et al. 2010) that could be used in conjunction with retrospective air quality simulations to better understand the causes of pollution events such as high-ozone episodes. Since high-ozone days in the northeastern United States often occur with synoptic surface winds from the southwest direction (Loughner et al. 2014; Hegarty et al. 2007; Seaman and Michelson 2000; Hogrefe et al. 2004; Gaza 1998), this uncertainty characterization of the mixingheight estimates could be of significant importance.

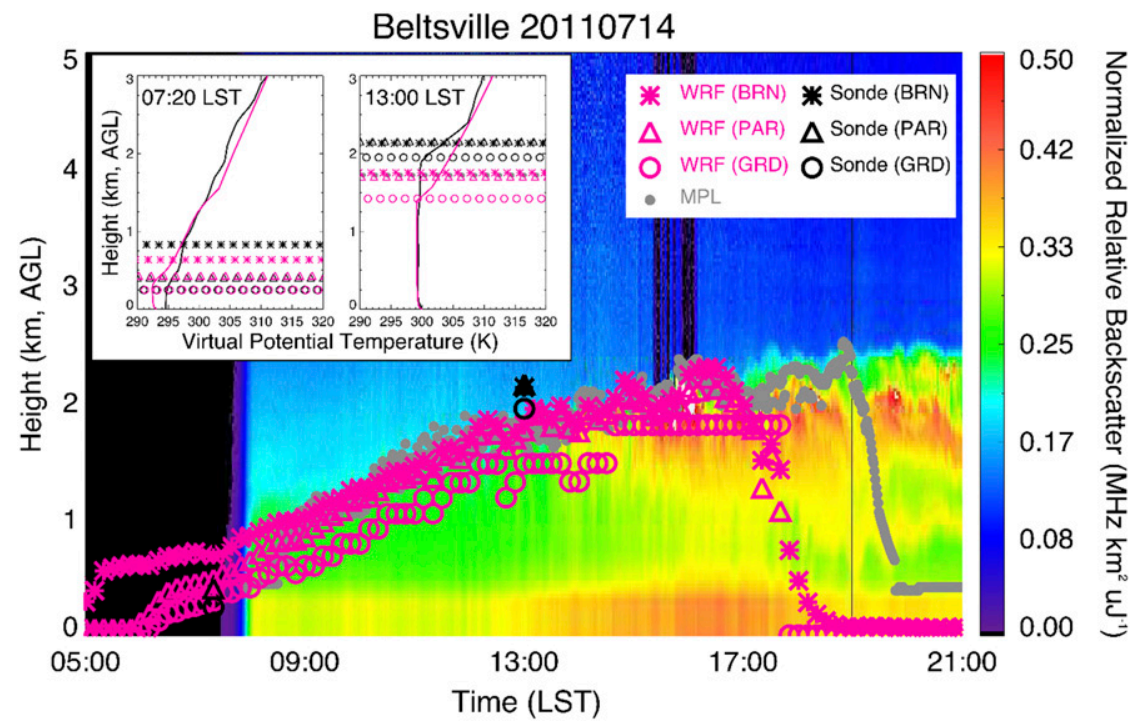

FIG. 9. As in Fig. 8, but for 14 Jul 2011. The profiles of ozonesonde (black) and WRF (pink) virtual potential temperatures are at 0720 and 1300 LST. For this day, there are no MPL data at BELT before 0800 LST, and these times are shown as the background color. 
TABLE 4. The WRF correlation, bias ( $\mathrm{km}$; WRF - MPL), and root-mean-square difference $(\mathrm{km})$ for PBLH when compared with MPL PBLHs at UMBC for 0700-2000 LST, segregated by days with prevailing wind from the SW-W and NW-SE directions at BWI. The WRF PBLHs are calculated using the BRN, PAR, and GRD methods, and the statistics are listed in that order in each cell.

\begin{tabular}{lccr}
\hline \hline \multicolumn{1}{c}{ WRF configuration } & $R$ & \multicolumn{1}{c}{ Bias } & RMSD \\
\hline SW-W winds & & & $0.43,0.28,0.11$ \\
BouLac-BEPBEM-MURSST & $0.58,0.58,0.65$ & $0.32,0.17,-0.02$ & $0.76,0.76,0.58$ \\
MYJ-BEPBEM-MURSSST & $0.55,0.55,0.55$ & $0.29,0.14,-0.04$ & $0.72,0.71,0.68$ \\
MYJ-BEPBEM-noMURSST & $0.57,0.58,0.55$ & $0.48,0.38,-0.06$ & $0.70,0.70,0.68$ \\
MYJ-noUCM-MURSST & $0.62,0.61,0.58$ & & $0.82,0.80,0.66$ \\
NW-SE winds & & $0.26,0.14,-0.05$ & $0.64,0.63,0.54$ \\
BouLac-BEPBEM-MURSST & $0.57,0.58,0.61$ & $0.19,0.08,-0.12$ & $0.61,0.60,0.60$ \\
MYJ-BEPBEM-MURSSST & $0.58,0.58,0.56$ & $0.22,0.10,-0.07$ & $0.64,0.62,0.60$ \\
MYJ-BEPBEM-noMURSST & $0.56,0.57,0.56$ & $0.37,0.29,-0.11$ & $0.68,0.64,0.55$ \\
MYJ-noUCM-MURSST & $0.64,0.65,0.64$ & & \\
\hline
\end{tabular}

Finding poor WRF-HSRL-1 correlations on several other days with wind flow from the southwest to west (SW-W) directions prompted a recalculation of the WRF-HSRL-1 and UMBC WRF-MPL PBLH statistics segregated by the daily average wind directions at BWI (Tables 4 and 5). Although the differences based on wind direction were smaller than those for the 11 and 14 July cases, generally the WRF-lidar PBLH correlations were lower and the biases were higher on days with $\mathrm{SW}-\mathrm{W}$ winds.

In BW, the Chesapeake Bay breeze can also affect the PBL by transporting cooler, more stable marine air over land producing an internal thermally stable layer near the surface, effectively lowering the mixing height (e.g., Stauffer et al. 2015). This development could potentially affect the PBLH derived from WRF and ozonesonde profiles and from lidars near the coastline lowering the PBLH earlier in the afternoon. Stauffer et al. (2015) identified five days, 2, 5, 23, 26, and 29 July, on which the bay breeze occurred while Loughner et al. (2014) identified 11 July as an additional bay-breeze day. At EDGE, near the coast, the MPL showed evidence of an early PBLH decrease only on 5 and 29 July, while the
WRF PBLHs showed an early PBLH descent on all six days. Two of the six days, 11 and 29 July, were studied in more detail as they had different MPL behavior and both had ozonesonde launches late in the afternoon that could potentially show the bay-breeze influence.

On 11 July, the MPL and WRF (BRN and PAR) PBLH grew to about $1.6 \mathrm{~km}$ and the ozonesonde BRN PBLH reached $1.1 \mathrm{~km}$ by 1434 LST (Fig. 10). By 1633 LST the WRF PBLHs, except for BRN, and the ozonesonde PBLHs had lowered to $<0.75 \mathrm{~km}$. The WRF BRN PBLH lowered to near that level about $1 \mathrm{~h}$ later. However, the MPL PBLHs remained near $1.6 \mathrm{~km}$ through 2100 LST. On 29 July, the MPL PBLH retrievals grew to a peak value of $2.25 \mathrm{~km}$ by 1600 LST then decreased rapidly to $\sim 0.5 \mathrm{~km}$ by 1800 LST (Fig. 11). The WRF PBLH grew more rapidly with WRF BRN and PAR values exceeding $1.6 \mathrm{~km}$ by $1130 \mathrm{LST}$, which compared well with the corresponding 1138 LST ozonesonde values. The WRF PBLHs reached a height of $\sim 2 \mathrm{~km}$ by $1500 \mathrm{LST}$ and then descended rapidly to $\sim 0.6 \mathrm{~km}$ by $1630 \mathrm{LST}$, which compared well to the 1621 LST ozonesonde PBLHs.

TABLE 5. The WRF PBLH correlation, bias ( $\mathrm{km}$; WRF - HSRL-1), and root-mean-square difference (km) when compared with HSRL-1 PBLHs for days with prevailing wind directions from the SW-W and NW-SE directions at BWI. The WRF PBLHs are calculated using the BRN, PAR, and GRD methods, and the statistics are listed in that order in each cell.

\begin{tabular}{llll}
\hline \hline \multicolumn{1}{c}{ WRF configuration } & \multicolumn{1}{c}{$R$} & \multicolumn{1}{c}{ Bias } & \multicolumn{1}{c}{ RMSD } \\
\hline SW-W winds & & & $0.90,0.91,0.77$ \\
BouLac-BEPBEM-MURSST & $0.37,0.34,0.44$ & $0.26,0.15,-0.19$ & $0.95,0.97,0.92$ \\
MYJ-BEPBEM-MURSSST & $0.25,0.23,0.29$ & $0.17,0.06,-0.32$ & $0.08,-0.02,-0.35$ \\
MYJ-BEPBEM-noMURSST & $0.26,0.24,0.30$ & $0.24,0.13,-0.33$ & $0.91,0.92,0.85$ \\
MYJ-noUCM-MURSST & $0.34,0.32,0.39$ & & 0.93 \\
NW-SE winds & & $0.16,0.10,-0.21$ & $0.54,0.54,0.52$ \\
BouLac-BEPBEM-MURSST & $0.66,0.66,0.64$ & $0.13,0.06,-0.28$ & $0.0 .50,0.57$ \\
MYJ-BEPBEM-MURSSST & $0.69,0.68,0.63$ & $0.04,-0.03,-0.32$ & $0.56,0.58,0.62$ \\
MYJ-BEPBEM-noMURSST & $0.62,0.60,0.58$ & $0.17,0.11,-0.31$ & $0.52,0.52,0.57$ \\
MYJ-noUCM-MURSST & $0.69,0.68,0.64$ & & \\
\hline
\end{tabular}




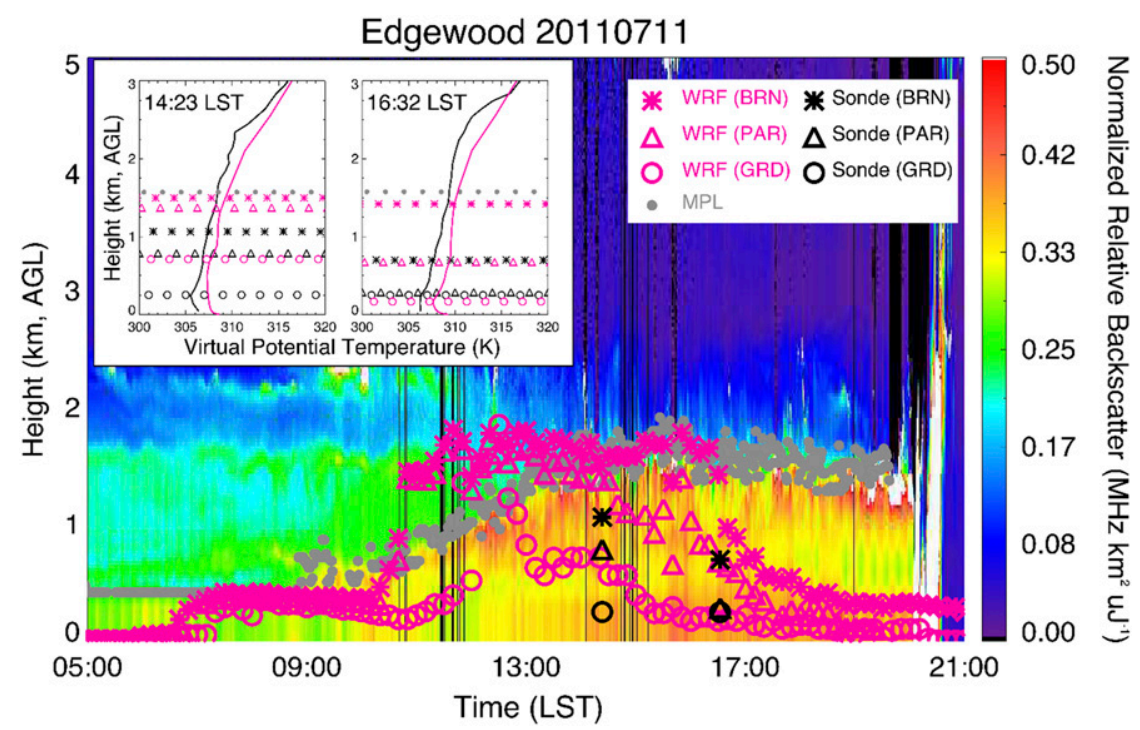

FIG. 10. As in Fig. 8, but at EDGE. The profiles of ozonesonde (black) and WRF (pink) virtual potential temperatures are at 1423 and 1632 LST.

For both cases, WRF simulated vertical profiles that were generally consistent with the ozonesondes. The apparent rapid descent in the PBLH in the afternoon was associated with the development of shallow layers of relatively lower virtual potential temperatures near the surface from the onshore flow of cooler, more stable marine air that effectively lowered the mixing depth. This shallow $(0.3-0.6 \mathrm{~km})$ depth is near or below the lowest available height of the MPL NRB profiles and therefore generally not detectable. That the MPL PBLH remained high on 11 July, but appeared to descend late in the afternoon on 29 July may possibly be more attributable to differences in the synoptic conditions on the two days than differences in the mesoscale baybreeze circulations. On 11 July, a large anticyclone located off the east coast produced a general southwest flow and stagnant conditions restricting dilution of the aerosols that built up in the PBL. On 29 July, a synopticscale trough crossed the domain ahead of a cold front, which may have enabled some dilution of the aerosols that would have remained in the residual layer after the surface was cut off by the stable layer that formed from the bay breeze. The curtain plots suggest that the aerosol backscatter on 29 July decreased near the top of the PBL even before the PBLH began to rapidly decrease late in the day. Therefore, it is possible that the apparent influence of the bay breeze on the MPL PBLH was made detectable by the dilution of the upper portion of the residual layer, making any remaining gradient near the lowest level of the NRB profile more distinct.

\section{Summary}

The daytime PBL over the BW region was examined for July 2011 using data from ground-based MPLs, airborne HSRL-1, and ozonesondes generated for the DISCOVERAQ field campaign, MPL data from MPLNET and MPL, and radiosonde data from the NOAA/NWS/OBS center at STER, the orbiting CALIPSO satellite, and highresolution WRF simulations. The PBLHs were retrieved from aerosol backscatter gradients measured by the lidars and derived from vertical profiles of temperature, moisture, and winds observed by ozonesondes and radiosondes and simulated by WRF using the BRN, PAR, and GRD methods.

At all locations examined, the MPLs and WRF depicted a PBL growing from a morning height of a few hundred meters to $>1.5 \mathrm{~km}$ by early afternoon. The WRF PBL grew faster and reached a peak value earlier than indicated by the MPL retrievals. The peak WRF PBLHs from BRN and PAR were positively biased relative to the MPLs by $\sim 0.3 \mathrm{~km}$ while the GRD method produced smaller biases. Simulations using the BouLac PBL scheme and without the BEPBEM UCM parameterization produced higher biases than those with the MYJ PBL scheme and the BEPBEM UCM turned on. At BELT, a few kilometers from GSFC, MPL PBLHs were in better statistical agreement with PBLHs derived from ozonesondes than with WRF, suggesting that the WRF-MPL differences at the inland locations were primarily due to model error. The impact of the SST inputs to WRF only affected the simulated PBLH at the coastal EDGE location with the colder NARR SSTs 


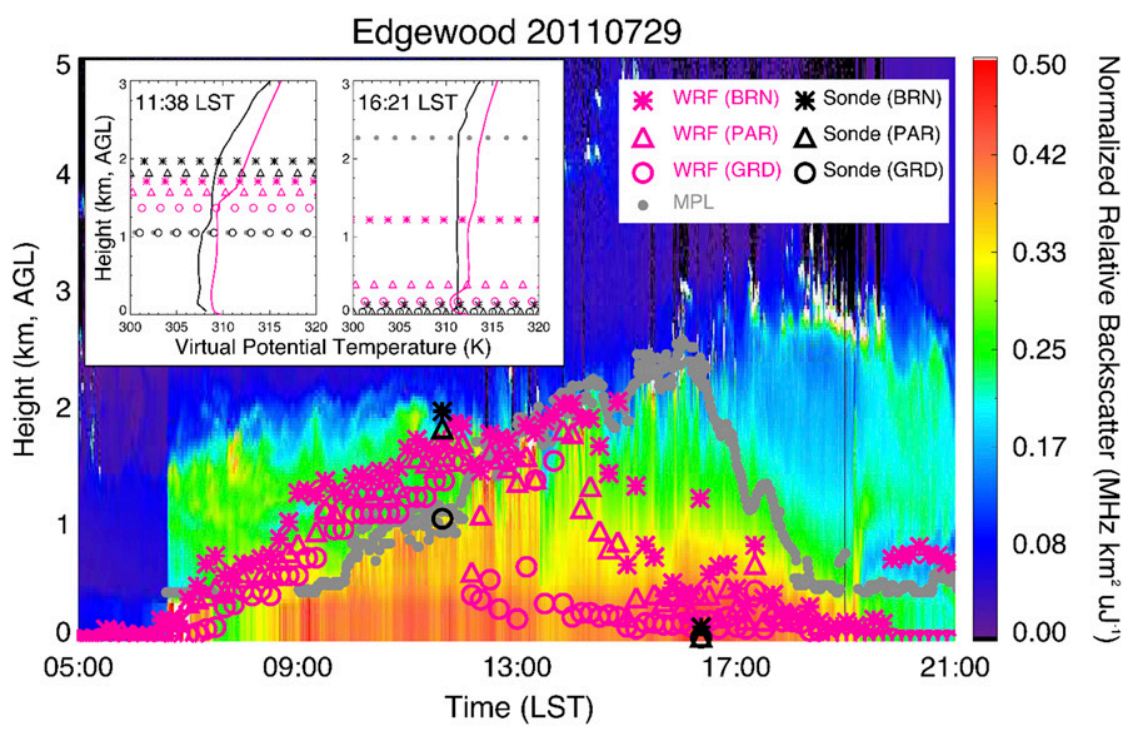

FIG. 11. As in Fig. 10, but for 29 Jul 2011. The profiles of ozonesonde (black) and WRF (pink) virtual potential temperatures are at 1138 and 1621 LST.

producing less positive model biases than the warmer MURSSTs.

At all locations, the WRF PBLH also descended earlier than the MPL retrievals indicated. A comparison between MPL, radiosonde, and WRF PBLHs from STER at $1900 \mathrm{LST}$, about $0.5 \mathrm{~h}$ before sunset, indicated that at inland locations the descent of the WRF PBLH was too early. However, at EDGE near the coast, the earlier descent of the WRF PBLH appeared to be due to the bay breeze. Here WRF PBLHs decreased significantly in early or midafternoon on all days identified in previous studies as having bay breezes while the MPL PBLHs only showed signs of an early descent on two of these days and then only much later in the afternoon. In contrast, the WRF PBLHs compared favorably to ozonesonde PBLHs for two of the bay-breeze days with afternoon ozonesonde launches that captured the change in the vertical PBL structure. The inability of the MPL PBLH data to show these changes was likely due to the lack of NRB profile data below $340 \mathrm{~m}$, which limited the lowest PBLH to $\sim 450 \mathrm{~m}$, a height that was generally close to or above the top of the lower stable layer that develops as the air moves onshore with the bay breeze.

The comparisons between WRF PBLHs and the HSRL-1 and CALIPSO PBLHs produced similar findings to those with the MPLs. While the HSRL-1 flight tracks were mostly over the same BW urban corridor being sampled by the MPLs, the CALIPSO ground tracks were to the east over eastern Maryland and to the west over central Virginia and western Maryland. The CALIPSO PBLHs showed a strong east-west gradient qualitatively consistent with WRF simulations with lower values for the western tracks than the eastern tracks associated with different underlying land surface characteristics.

The WRF-lidar PBLH comparisons exhibited dependence on synoptic conditions. On days with southwest winds, WRF-lidar PBLH correlations were lower and WRF biases higher than on days with other wind directions. In addition, cases studies showed that there were larger differences in the PBLHs calculated with different methods from both the WRF and ozonesonde profiles on a day with southwest winds and warm humid conditions than on a day with northerly flow and cooler drier conditions. This suggests that the meteorological PBL structure is less distinct and there is greater uncertainty in the mixing height that can be derived from meteorological profiles under certain synoptic conditions. This is an important consideration since warmseason days with winds from the southwest in the northeastern United States tend to be associated with high levels of pollutants such as ozone, and the uncertainty in the mixing-height estimates could complicate retrospective air quality studies of high-pollution episodes as well as operational air quality forecasts. Lidar data, if routinely available, might help provide a better estimate of the mixing height.

Several recommendations for future work involving lidars and modeling to study the PBL can be made from this study. First, lidar data should extend as near to the surface as possible $(\sim 100-200 \mathrm{~m})$ with high vertical resolution (at least $30 \mathrm{~m}$ ) in order to estimate the mixing height under the influence of sea, bay, or lake breezes, and would extend the effective temporal coverage into 
the early evening and early morning. Second, groundbased lidar coverage could be extended to more rural areas to better monitor the urban-rural PBLH gradient. Third, more work needs to be done to quantify the uncertainty of the mixing height on days when synoptic conditions make the meteorological PBL structure less distinct.

Acknowledgments. This work was supported under the NASA Atmospheric Composition Campaign Data Analysis and Modeling program under Grant NNH14CM13C. The MPLNET project is funded by the NASA Radiation Sciences Program and Earth Observing System. The MPL data for DISCOVER-AQ were produced by Tim Berkoff, and the ozonesonde launches and data processing were coordinated by Everette Joseph at Beltsville and Anne Thompson at Edgewood. The CALIPSO data were obtained from the NASA Langley Research Center Atmospheric Science Data Center. We also thank Robert Gilliam of the U.S. EPA for providing us with software to process the MURSST.

\section{REFERENCES}

Angevine, W. M., A. B. White, C. J. Senff, M. Trainer, R. M. Banta, and M. A. Ayoub, 2003: Urban-rural contrasts in mixing height and cloudiness over Nashville in 1999. J. Geophys. Res., 108, 4092, https://doi.org/10.1029/2001JD001061.

—, L. Eddington, K. Durkee, C. Fairall, L. Bianco, and J. Brioude, 2012: Meteorological model evaluation for CalNex 2010. Mon. Wea. Rev., 140, 3885-3906, https://doi.org/10.1175/ MWR-D-12-00042.1.

Baker, K. R., C. Misenis, M. D. Obland, R. A. Ferrare, A. J. Scarino, and J. T. Kelly, 2013: Evaluation of surface and upper air fine scale WRF meteorological modeling of the May and June 2010 CalNex period in California. Atmos. Environ., 80, 299-309, https://doi.org/10.1016/j.atmosenv.2013.08.006.

Banks, R. F., J. Tiana-Alsina, F. Rocadenbosch, and J. M. Baldasano, 2015: Performance evaluation of the boundary-layer height from lidar and the Weather Research and Forecasting Model at an urban coastal site in the north-east Iberian Peninsula. Bound.-Layer Meteor., 157, 265-292, https://doi.org/ 10.1007/s10546-015-0056-2.

_ — J. M. Baldasano, F. Rocadenbosch, A. Papayannis, S. Solomos, and C. G. Tzanis, 2016: Sensitivity of boundarylayer variables to PBL schemes in the WRF Model based on surface meteorological observations, lidar, and radiosondes during the HygrA-CD campaign. Atmos. Res., 176, 185-201, https://doi.org/10.1016/j.atmosres.2016.02.024.

Banta, R. M., and Coauthors, 1998: Daytime buildup and nighttime transport of urban ozone in the boundary layer during a stagnation episode. J. Geophys. Res., 103, 22519-22544, https://doi.org/10.1029/98JD01020.

Berman, S., J.-Y. Ku, and S.-T. Rao, 1999: Spatial and temporal variation in the mixing depth over the northeastern United States during the summer of 1995. J. Appl. Meteor., 38, 16611673, https://doi.org/10.1175/1520-0450(1999)038<1661: SATVIT $>2.0 . \mathrm{CO} ; 2$.

Bianco, L., and J. M. Wilczak, 2002: Convective boundary layer depth: Improved measurements by Doppler radar wind profiler using fuzzy logic methods. J. Atmos. Oceanic Technol., 19, 1745-1758, https://doi.org/10.1175/1520-0426(2002) $019<1745$ :CBLDIM $>2.0$. CO 2 .

Bohnenstengel, S. I., and Coauthors, 2015: Meteorology, air quality, and health in London: The Clearflo Project. Bull. Amer. Meteor. Soc., 96, 779-804, https://doi.org/10.1175/BAMS-D-12-00245.1.

Bougeault, P., and P. Lacarrere, 1989: Parameterization of orographyinduced turbulence in a mesobeta-scale model. Mon. Wea. Rev., 117, 1872-1890, https://doi.org/10.1175/1520-0493(1989) 117<1872:POOITI $>2.0 . \mathrm{CO} ; 2$.

Brooks, I. M., 2003: Finding boundary layer top: Application of a wavelet covariance transform to lidar backscatter profiles. J. Atmos. Oceanic Technol., 20, 1092-1105, https://doi.org/ 10.1175/1520-0426(2003)020<1092:FBLTAO > 2.0.CO;2.

Browning, K. A., and Coauthors, 2007: The Convective Storm Initiation Project. Bull. Amer. Meteor. Soc., 88, 1939-1955, https://doi.org/10.1175/BAMS-88-12-1939.

Burton, S. P., and Coauthors, 2010: Using airborne high spectral resolution lidar data to evaluate combined active plus passive retrievals of aerosol extinction profiles. J. Geophys. Res., $\mathbf{1 1 5}$ D00H15, https://doi.org/10.1029/2009JD012130.

Canny, J., 1986: A computational approach to edge detection. IEEE Trans. Pattern Anal. Mach. Intell., 8, 679-698, https:// doi.org/10.1109/TPAMI.1986.4767851.

Chen, F., and J. Dudhia, 2001: Coupling an advanced land surfacehydrology model with the Penn State-NCAR MM5 modeling system. Part I: Model implementation and sensitivity. Mon. Wea. Rev., 129, 569-585, https://doi.org/10.1175/1520-0493(2001) $129<0569$ :CAALSH $>2.0$. CO;2.

_ S. Miao, M. Tewari, J.-W. Bao, and H. Kusaka, 2011a: A numerical study of interactions between surface forcing and sea breeze circulations and their effects on stagnation in the greater Houston area. J. Geophys. Res., 116, D12105, https:// doi.org/10.1029/2010JD015533.

— system: Development, evaluation, and applications to urban environmental problems. Int. J. Climatol., 31, 273-288, https:// doi.org/10.1002/joc. 2158 .

Chin, T. M., J. Vazquez, and E. Armstrong, 2013: A multi-scale, high-resolution analysis of global sea surface temperature, version 1.3. NASA Jet Propulsion Laboratory Algorithm Theoretical Basis Doc. 13 pp., ftp://mariana.jpl.nasa.gov/mur_sst/ tmchin/docs/ATBD/old/atbd_1.3.pdf.

Cordero, L., N. Malakar, Y. Wu, B. Gross, and F. Moshary, 2013: Assessing surface PM2.5 estimates using data fusion of active and passive remote sensing methods. Br. J. Environ. Climate Change, 3, 547-565, https://doi.org/10.9734/BJECC/2013/7668.

Davis, K. J., D. H. Lenschow, S. P. Oncley, C. Kiemle, G. Ehret, A. Giez, and J. Mann, 1997: Role of entrainment in surfaceatmosphere interactions over the boreal forest. J. Geophys. Res., 102, 29219-29 230, https://doi.org/10.1029/97JD02236.

— N. Namage, C. R. Hagelberg, C. Kiemle, D. H. Lenschow, and P. P. Sullivan, 2000: An objective method for deriving atmospheric structure from airborne lidar observations. J. Atmos. Oceanic Technol., 17, 1455-1468, https://doi.org/ 10.1175/1520-0426(2000)017<1455:AOMFDA > 2.0.CO;2.

Fast, J. D., W. I. Gustafson Jr., E. G. Chapman, R. C. Easter, J. Rishel, R. A. Zaveri, G. Grell, and M. Barth, 2011: The Aerosol Modeling Testbed: A community tool to objectively evaluate aerosol process modules. Bull. Amer. Meteor. Soc., 92, 343-360, https://doi.org/10.1175/2010BAMS2868.1.

Feng, S., and Coauthors, 2016: Los Angeles megacity: A highresolution land-atmosphere modelling system for urban $\mathrm{CO}_{2}$ 
emissions. Atmos. Chem. Phys., 16, 9019-9045, https://doi.org/ 10.5194/acp-16-9019-2016.

Flamant, C., J. Pelon, P. H. Flamant, and P. Durand, 1997: Lidar determination of the entrainment zone thickness at the top of the unstable marine atmospheric boundary layer. Bound.-Layer Meteor., 83, 247-284, https://doi.org/10.1023/A:1000258318944.

Gaza, R. S., 1998: Mesoscale meteorology and high ozone in the northeastern United States. J. Appl. Meteor., 37, 961-977, https:// doi.org/10.1175/1520-0450(1998)037<0961:MMAHOI>2.0.CO;2.

Gerbig, C., S. Korner, and J. C. Lin, 2008: Vertical mixing in atmospheric tracer transport models: Error characterization and propagation. Atmos. Chem. Phys., 8, 591-602, https://doi.org/ 10.5194/acp-8-591-2008.

Grabon, J. S., K. J. Davis, C. Kiemle, and G. Ehret, 2010: Airborne lidar observations of the transition zone between the convective boundary layer and free atmosphere during the International $\mathrm{H}_{2} \mathrm{O}$ Project (IHOP) in 2002. Bound.-Layer Meteor., 134 61-83, https://doi.org/10.1007/s10546-009-9431-1.

Hair, J. W., and Coauthors, 2008: Airborne High Spectral Resolution Lidar for profiling aerosol optical properties. Appl. Opt., 47, 6734-6752, https://doi.org/10.1364/AO.47.006734.

Hayden, K. L., and Coauthors, 1997: The vertical chemical and meteorological structure of the boundary layer in the Lower Fraser Valley during Pacific '93. Atmos. Environ., 31, 20892105, https://doi.org/10.1016/S1352-2310(96)00300-7.

Heffter, J. L., 1980: Transport layer depth calculations. Proc. Second Joint Conf. on Applications of Air Pollution Meteorology and Second Conf. on Industrial Meteorology, New Orleans, LA, Amer. Meteor Soc., 787-791.

Hegarty, J., H. Mao, and R. Talbot, 2007: Synoptic controls on summertime surface ozone in the northeastern United States. J. Geophys. Res., 112, D14306, https://doi.org/10.1029/ 2006JD008170.

Hildebrand, P. H., and B. Ackerman, 1984: Urban effects on the convective boundary layer. J. Atmos. Sci., 41, 76-91, https://doi.org/ 10.1175/1520-0469(1984)041<0076:UEOTCB >2.0.CO;2.

Hogrefe, C., and Coauthors, 2004: Simulating regional-scale ozone climatology over the eastern United States: Model evaluation results. Atmos. Environ., 38, 2627-2638, https://doi.org/10.1016/ j.atmosenv.2004.02.033.

Holzworth, G. C., 1964: Estimates of mean maximum mixing depths in the contiguous United States. Mon. Wea. Rev., 92, 235-242, https://doi.org/10.1175/1520-0493(1964)092<0235: EOMMMD $>2.3 . \mathrm{CO} ; 2$.

Janjić, Z. I., 1994: The step-mountain eta coordinate model: Further developments of the convection, viscous layer, and turbulence closure schemes. Mon. Wea. Rev., 122, 927-945, https://doi.org/ 10.1175/1520-0493(1994)122<0927:TSMECM>2.0.CO;2.

_ 2001: Nonsingular Implementation of the Mellor-Yamada level 2.5 Scheme in the NCEP Meso model. NCEP Office Note 437, 61 pp., https://repository.library.noaa.gov/view/noaa/ 11409/noaa_11409_DS1.pdf.

Jordan, N. S., R. M. Hoff, and J. T. Bacmeister, 2010: Validation of Goddard Earth Observing System-version 5 MERRA planetary boundary layer heights using CALIPSO. J. Geophys. Res., 115, D24218, https://doi.org/10.1029/2009JD013777.

Kiemle, C., G. Ehret, A. Giez, K. J. Davis, D. H. Lenschow, and S. P. Oncley, 1997: Estimation of boundary layer humidity fluxes and statistics from airborne differential absorption lidar (DIAL). J. Geophys. Res., 102, 29189-29203, https://doi.org/ 10.1029/97JD01112.

Klir, G. J., and B. Yuan, 1997: Fuzzy Set Theory Foundations and Applications. Prentice Hall, 245 pp
Kusaka, H., H. Kondo, Y. Kikegawa, and F. Kimura, 2001: A simple single-layer urban canopy model for atmospheric models: Comparison with multi-layer and slab models. Bound.-Layer Meteor., 101, 329-358, https://doi.org/10.1023/ A:1019207923078.

LeMone, M. A., M. Tewari, F. Chen, and J. Dudhia, 2013: Objectively determined fair-weather CBL depths in the ARW-WRF model and their comparison to CASES-97 observations. Mon. Wea. Rev., 141, 30-54, https://doi.org/10.1175/MWR-D-12-00106.1.

Lewis, J. R., R. J. DeYoung, R. A. Ferrare, and A. Chu, 2010: Comparison of summer and winter California Central Valley aerosol distributions from lidar and MODIS measurements. Atmos. Environ., 44, 4510-4520, https://doi.org/ 10.1016/j.atmosenv.2010.07.006.

, E. J. Welton, A. M. Molod, and E. Joseph, 2013: Improved boundary layer depth retrievals from MPLNET. J. Geophys. Res. Atmos., 118, 9870-9879, https://doi.org/ 10.1002/jgrd.50570.

Lin, J. C., C. Gerbig, S. C. Wofsy, A. E. Andrews, B. C. Daube, K. J. Davis, and A. Grainger, 2003: A near-field tool for simulating the upstream influence of atmospheric observations: The stochastic time-inverted Lagrangian transport (STILT) model. J. Geophys. Res., 108, 4493, https://doi.org/10.1029/ 2002JD003161.

Lothon, M., and Coauthors, 2014: The BLLAST field experiment: Boundary-Layer Late Afternoon and Sunset Turbulence. Atmos. Chem. Phys., 14, 10 931-10 960, https://doi.org/10.5194/ acp-14-10931-2014.

Loughner, C. P., and Coauthors, 2014: Impact of bay-breeze circulations on surface air quality and boundary layer export. J. Appl. Meteor., 53, 1697-1713, https://doi.org/10.1175/ JAMC-D-13-0323.1.

Martilli, A., A. Clappier, and M. W. Rotach, 2002: An urban surface exchange parameterization for mesoscale models. Bound.-Layer Meteor., 104, 261-304, https://doi.org/10.1023/ A:1016099921195.

McGrath-Spangler, E. L., and A. S. Denning, 2012: Estimates of North American summertime planetary boundary layer depths derived from space-borne lidar. J. Geophys. Res., 117, D15101, https://doi.org/10.1029/2012JD017615.

— , and - 2013: Global seasonal variations of midday planetary boundary layer depth from CALIPSO space-borne LIDAR. J. Geophys. Res. Atmos., 118, 1226-1233, https://doi.org/ 10.1002/jgrd.50198.

McKain, K., S. C. Wofsy, T. Nehrkorn, J. Eluszkiewicz, J. R. Ehleringer, and B. B. Stephens, 2012: Assessment of groundbased atmospheric observations for verification of greenhouse gas emissions from an urban region. Proc. Natl. Acad. Sci. USA, 109, 8423-8428, https://doi.org/10.1073/pnas.1116645109.

Melfi, S. H., J. D. Sphinhirne, S. H. Chou, and S. P. Palm, 1985: Lidar observations of the vertically organized convection in the planetary boundary layer over the ocean. J. Climate Appl. Meteor., 24, 806-821, https://doi.org/10.1175/1520-0450(1985) $024<0806$ :LOOVOC $>2.0 . \mathrm{CO} ; 2$.

Mesinger, F., and Coauthors, 2006: North American Regional Reanalysis. Bull. Amer. Meteor. Soc., 87, 343-360, https://doi.org/ 10.1175/BAMS-87-3-343.

Mitchell, K., and Coauthors, 2005: The Community Noah LandSurface Model (LSM) user's guide, public release version 2.7.1. National Centers for Environmental Prediction/Environmental Modeling Center Tech. Doc., 26 pp., ftp://ftp.emc. ncep.noaa.gov/mmb/gcp/ldas/noahlsm/ver_2.7.1/Noah_LSM_ USERGUIDE_2.7.1.doc. 
Monaghan, A. J., L. Hu, N. A. Brunsell, M. Barlage, and O. V. Wilhelmi, 2014: Evaluating the impact of urban morphology configurations on the accuracy of urban canopy model temperature simulations with MODIS. J. Geophys. Res. Atmos., 119, 6376-6392, https://doi.org/10.1002/2013JD021227.

Nehrkorn, T., J. Henderson, M. Leidner, M. Mountain, J. Eluszkiewicz, K. McKain, and S. C. Wofsy, 2013: WRF simulations of the urban circulation in the Salt Lake City area for $\mathrm{CO}_{2}$ modeling. J. Appl. Meteor. Climatol., 52, 323-340, https://doi.org/10.1175/JAMC-D-12-061.1.

Rogers, R. R., and Coauthors, 2009: NASA LaRC airborne high spectral resolution lidar aerosol measurements during MILAGRO: Observations and validation. Atmos. Chem. Phys., 9, 4811-4826, https://doi.org/10.5194/acp-9-4811-2009.

Salamanca, F., and A. Martilli, 2010: A new building energy model coupled with and urban canopy parameterization for urban climate simulations-Part II. Validation with one dimension off-line simulations. Theor. Appl. Climatol., 99, 345-356, https://doi.org/10.1007/s00704-009-0143-8.

Scarino, A. J., and Coauthors, 2014: Comparison of mixed layer heights from airborne high spectral resolution lidar, groundbased measurements, and the WRF-Chem model during CalNex and CARES. Atmos. Chem. Phys., 14, 5547-5560, https://doi.org/10.5194/acp-14-5547-2014.

Seaman, N., and S. Michelson, 2000: Mesoscale meteorological structure of a high-ozone episode during the 1995 NARSTONortheast study. J. Appl. Meteor., 39, 384-398, https://doi.org/ 10.1175/1520-0450(2000)039<0384:MMSOAH>2.0.CO;2.

Seibert, P., F. Beyrich, S. Gryning, S. Joffre, A. Rasmussen, and P. Tercier, 2000: Review and intercomparison of operational methods for the determination of the mixing height. Atmos. Environ., 34, 1001-1027, https://doi.org/10.1016/S1352-2310 (99)00349-0.

Seidel, D. J., C. O. Ao, and K. Li, 2010: Estimating climatological planetary boundary layer heights from radiosonde observations: Comparison of methods and uncertainty analysis. J. Geophys. Res., 115, D16113, https://doi.org/10.1029/2009JD013680.

Y. Zhang, A. Beljaars, J.-C. Golaz, A. R. Jacobson, and B. Medeiros, 2012: Climatology of the planetary boundary layer over the continental United States and Europe. J. Geophys. Res., 117, D17106, https://doi.org/10.1029/2012JD018143.
Skamarock, W. C., and J. B. Klemp, 2008: A time-split nonhydrostatic atmospheric model for weather research and forecasting applications. J. Comput. Phys., 227, 3465-3485, https://doi.org/10.1016/j.jcp.2007.01.037.

Spangler, T. C., and R. A. Dirks, 1974: Meso-scale variations of the urban mixing height. Bound.-Layer Meteor., 6, 423-441, https://doi.org/10.1007/BF02137677.

Stauffer, R. M., and Coauthors, 2015: Bay breeze influence on surface ozone at Edgewood, MD during July 2011. J. Atmos. Chem., 72, 335-353, https://doi.org/10.1007/s10874-012-9241-6.

Stull, R. B., 1988: An Introduction to Boundary Layer Meteorology. Kluwer Academic, 666 pp.

Trainer, M., B. A. Ridley, M. P. Buhr, G. Kok, J. Walega, G. Hübler, D. D. Parrish, and F. C. Fehsenfeld, 1995: Regional ozone and urban plumes in the southeastern United States: Birmingham, a case study. J. Geophys. Res., 100, 18 823-18 834, https://doi.org/ 10.1029/95JD01641.

Wang, W., and Coauthors, 2015: Weather Research and Forecasting ARW version 3 modeling system user's guide. NCAR MMM Division Tech. Rep., 428 pp., http://www2.mmm.ucar.edu/ wrf/users/docs/user_guide_V3.6/ARWUsersGuideV3.6.1.pdf.

Ware, J., E. A. Kort, P. DeCola, and R. Duren, 2016: Aerosol lidar observations of atmospheric mixing in Los Angeles: Climatology and implications for greenhouse gas observations. J. Geophys. Res. Atmos., 121, 9862-9878, https://doi.org/ 10.1002/2016JD024953.

Welton, E. J., J. R. Campbell, J. D. Spinhirne, and V. S. Scott, 2001: Global monitoring of clouds and aerosols using a network of micropulse lidar systems. Proc. SPIE, 4153, 151-158, https:// doi.org/10.1117/12.417040.

Winker, D. M., W. H. Hunt, and M. J. McGill, 2007: Initial performance assessment of CALIOP. Geophys. Res. Lett., 34, L19803, https://doi.org/10.1029/2007GL030135.

—_, M. A. Vaughan, A. Omar, Y. Hu, K. A. Powell, Z. Liu, W. H. Hunt, and S. A. Young, 2009: Overview of the CALIPSO mission and CALIOP data processing algorithms. J. Atmos. Oceanic Technol., 26, 2310-2323, https://doi.org/ 10.1175/2009JTECHA1281.1.

Wyngaard, J. C., 2004: Toward numerical modeling in the "terra incognita." J. Atmos. Sci., 61, 1816-1826, https://doi.org/ 10.1175/1520-0469(2004)061<1816:TNMITT>2.0.CO;2. 